\title{
Tillit og kvalitet
}

Gro Hege Saltnes Urdal Høgskolen i Bergen

Gro.Hege.Saltnes.Urdal@hib.no

\author{
Keywords: \\ sign language \\ interpreting \\ control \\ trust \\ quality \\ collaboration
}




\section{Abstract}

\section{Trust and quality: two interdependent concepts}

A service is intangible, it is created and consumed in the here and now. Although it may be a challenging task to measure the quality of a service objectively, clearly some services are of good quality, while others are not.

The International Organization for Standardization (ISO) defines quality as "the degree to which a set of inherent characteristics fulfils requirements (or needs). "In other words, any service that meets users' expectations or needs will be of good quality. However, views will differ as to what constitutes good quality and how to achieve it.

This article is based on a study of deaf people who use interpreters and of hearing Sign Language interpreters. The study examined the parties' experiences of interaction in interpreting situations where the primary activity was interpretation from Norwegian Sign Language to spoken Norwegian. By considering situations from an interactional perspective, we have focused on how the parties create their social reality. We have also sought to pinpoint the influence of various factors on the experiences of deaf people and interpreters in interpreting situations; and have sought to identify what the parties believe characterizes an interpreting situation of good quality.

We produced our data by establishing two focus groups, one consisting of deaf people and one consisting of hearing Sign Language interpreters. When analysing the resulting data, our focus was on identifying the thoughts and experiences that determined the behaviour of both the deaf person and the hearing interpreter. Based on the thoughts of both parties regarding actions and experiences, we applied analytical tools based on ethnomethodology and concepts of indexicality and reflexivity. Our aim has been to examine the context in which the actions and experiences were described, and to apply different perspectives to identify the nature of the interaction between the different analytical components.

Taking an interactional perspective, the article examines the various challenges that may arise in an interpreting situation. Such challenges may relate to communication; differences between Norwegian Sign Language and spoken Norwegian; and to the interpreting process itself. These challenges affect the interaction between the deaf person and the interpreter, making it more difficult to achieve a good-quality interpreting situation.

When communicating in an interpreting situation, the deaf person and the interpreter employ various control mechanisms when attempting to assess or improve the quality of the situation. Both deaf persons and interpreters mentioned attempting to exert control over the allocation of the interpreter/deaf person that they would be working with as a means of gaining visibility and control over the situation. Two factors that both parties believed could improve the quality of the interpreting situation and enhance their feelings of control were preparation and pre-discussion (a conversation between the deaf person and the interpreter that takes place in advance of a particular interpreting situation). In addition, during the interpreting session, both parties attempt to verify whether the interpreter has perceived an expression correctly. A central assumption in Goffman is that people attempt to control other people's impressions of them through expressions we give and give off. In an interpreted conversation, however, it will be extremely difficult for a deaf person to verify what the interpreter is saying, and accordingly what impression he or she is making on the deaf person's behalf. Since the interpreter often is the only party present who is familiar with both languages, this may cause tension between the deaf person and the interpreter.

Sign Language interpreting situations require collaboration between hearing persons, deaf persons, and interpreters. Situations that require collaboration often involve a mix of mutual monitoring and control, and trust. Since trust is a relevant factor, establishing trust is 
important. The deaf people and the interpreters in the focus groups referred to the concept of trust in different ways, and this in itself may say something about how trust is established. Both parties agreed, however, that while trust may be present from the outset, trust could also be built up over time. The process of the parties getting to know each other plays a major role in the building up of mutual trust. While it is sometimes argued that trust arises more from the behaviour of professional practitioners than from their qualifications and the quality of the work they perform, there is evidence that, in interpreting situations, trust and quality are intertwined. The nature of the interrelation between trust and quality is experienced differently, however, by deaf persons and by interpreters. On the one hand, a deaf person will trust the interpreter if she or he is confident that the quality of the interpretation is satisfactory. On the other hand, interpreters have to feel that they are trusted in order to perform in a qualitatively satisfactory manner. 


\section{Innledning}

En tjeneste er immateriell, den skapes og forbrukes her og nå. Selv om det kan være utfordrende å kvalitetsmåle tjenester på en objektiv måte, har vi likevel gjerne en bestemt oppfatning om at noen tjenester har en god kvalitet, mens andre ikke har det.

Den internasjonale standardiseringsorganisasjonen ISO definerer kvalitet som «i hvilken grad en samling av iboende egenskaper oppfyller krav (eller behov)». Dermed vil alt ved tjenesten som imøtekommer brukernes forventinger eller behov, være av god kvalitet. Imidlertid vil det være ulike oppfatninger om hva som er god kvalitet og hvordan man oppnår det.

Tolking er et eksempel på en tjeneste. Tolking kan defineres som

a form of translation in which a first and final rendition in another language is produced on the basis of a one-time presentation of an utterance in a source language (Pöchhacker, 2004, s. 11, referert i Skaaden, 2013, s. 18).

Tolken produserer og leverer, i øyeblikket, en oversettelse som konsumeres av tolkebrukerne. Tolkingen skjer simultant og mellom to parter som ikke, i hvert fall ikke uten besvær, kan kommunisere.

En tolk kan oversette mellom to talespråk eller mellom et tegnspråk og et talespråk. I denne sammenhengen snakker vi om norsk tegnspråk, som kan defineres som et gestueltvisuelt språk med symbolsystemer som uttrykkes simultant (Schröder 2006, s. 81). Med gestuelt mener vi at det utføres med bestemte bevegelser av hendene, armene, ansiktet, hodet og kroppen. (Mosand \& Malmquist, 1996, s. 30). Tegnspråk er et fullverdig språk med egen grammatikk på lik linje med andre språk. De fleste tegnspråklige tolkesituasjoner innebærer tolking begge veier mellom to språk, såkalt interlingual tolking (se Lomheim, 1995, s. 17). Studien denne artikkelen bygger på har fokus på tolking fra norsk tegnspråk til norsk tale, som i tolkediskurs gjerne kalles stemmetolking. En tolket kommunikasjonssituasjon har tre parter; døve, hørende og tolker. Mens både døve og hørende er brukere av tolkens tjenester, er det bare den døve parten som har rett til tolk i henhold til folketrygdloven.

En av tegnspråktolkens oppgaver er å «fremme likeverdig deltakelse og god samtaleflyt mellom partene» (Tolkeforbundet, 2011). Tolkebrukerne (døve og hørende) har likeverdige krav på tolkens kompetanse. Tolken kan på den måten sees på som to-partisk (Skaaden, 2013, s. 17). Det er viktig at tolken har gode ferdigheter i begge språk, har forståelse for og mestrer tolkeprosessen, har god konsentrasjonsevne samt tåler stress og er utholdende (Skaaden, 2013, s. 19). I tillegg skal tolken praktisere nøyaktighetsprinsippet, dvs. hele tiden gjengi det som uttrykkes av partene og nøytralitetsprinsippet, dvs. være upartisk, og ikke la egne holdninger eller meninger påvirke tolkesituasjonen (Skaaden 2013, s. 21).

Pålitelighet og om en tjeneste er tillitsskapende er faktorer som er med på å avgjøre om en tjeneste oppleves som tilfredsstillende. Dette er faktorer som relateres til både tolken og tolkingen. Kvaliteten vil måles av den enkelte bruker av tjenesten og er således subjektiv (Skaaden, 2013, s. 196). Tolking er i sitt vesen slik at målingen av kvalitet alltid vil være subjektiv, noe som medfører at det kan være variasjoner på hva den enkelte opplever som god kvalitet. Det må tolken forholde seg til. I enhver tolkesituasjon står tolken konstant overfor valg. Det kan blant annet være valg av ord og tegn, eller tolkens plassering i rommet. Det vil hele tiden være løsninger som er gode og mindre gode, og tolken må ta avgjørelser med kort betenkningstid. Dette arbeidet kan være ensomt og krevende. Tolken er likevel ikke alene om å ha ansvaret for kvaliteten i tolkingen. Skaaden $(2013$, s. 216) hevder at tolkens kvalitet er avhengig både av tolkens skjønnsutøvelse og betingelser og 
rammefaktorer i tolkesituasjonen. En av rammefaktorene kan være tolkens relasjon til brukerne i situasjonen. Når tjenester leveres i samspill med brukernes forutsetninger og deltakelse i situasjonen, vil også brukerne være med på skape tjenesten og fungere som medprodusenter (Brofoss, 2012, s. 234).

\section{Samspill og ekvivalens}

Hvis man ser tolking som et sosialt fenomen innenfor sosiolingvistikken, vil det som skjer utover selve oversettelsen også ha betydning. I et slikt perspektiv vil den sosiale samhandlingen mellom brukerne og tolken trekkes inn, og slik blir brukeren med på å «skape tjenestens kvalitet». Dette er i tråd med det Cecilia Wadensjö påpeker når hun skriver at (tolkede) samtaler utspiller seg i et samspill. Hun hevder at

den förståelse som deltagarna (inklusive tolken) etablerar, den mening som använda ord och uttryck får, är produkten av en kollektiv, social aktivitet och beroende av sociala konventioner, av deltagarnas kommunikativa projekt och skilda perspektiv samt av växelspelet dem emellan (Wadensjö, 1998, s. 46).

Under samspillet vil vilkårene skapes og omskapes hele tiden. Dermed vil tolken alene ikke kunne rå over de forutsetninger han eller hun arbeider under, som er lite bestemt på forhånd (Wadensjö, 1998, s. 43). Når samtalen foregår via tolk, vil det være mer utfordrende for partene å vite når de kan ta ordet og hvor lenge de kan beholde det. Det sekvensielle i samtalen blir utydelig. Tolken vil påvirke fordelingen av ansvaret for samtalens innhold og utvikling, og dette stiller krav til partenes fleksibilitet som talere og lyttere (Wadensjö, 1998, s. 43-44 og s. 114). I en tolket samtale er det hvordan partene relaterer seg til tolken og til hverandre som skaper den grunnleggende forutsetningen for kommunikasjonen (Wadensjö, 1998, s. 114). A se tolking som et samspill gjennom språklige handlinger, hører sammen med et dialogisk syn på språk og språkbruk. Det vil si at meningen med de språklige handlinger etableres mellom menneskene (Wadensjö, 1998, s. 20).

Dette kan sees i sammenheng med det sosiologen Erving Goffman (1992, s.20) hevder når han skriver at individer må forstås i relasjon til den sosiale konteksten. I møte med andre mennesker definerer vi situasjonen og den definisjonen danner utgangspunktet for det samspillet som oppstår. Vår evne til å uttrykke oss blir også tydelig i møte med andre mennesker. Goffman skiller mellom uttrykk vi gir, $d v s$ verbale eller tilsvarende symboler vi bruker for å formidle opplysninger og uttrykk vi avgir, dvs handlinger som er karakteriskiske for oss som handlende personer (1992, s. 12). Eventuelle feiltakelser vil i samtaler [uten tolk] som oftest bli korrigert eller dekket over like etter det har skjedd (Goffman, 1992, s. 43-44). Men i en tolkesituasjon vil de språklige ytringene som gis bli tolket av tolken, og tolkebrukerne har ikke alltid mulighet til à oppfatte hvordan de blir tolket. Hvis det skjer en tolkefeil verken tolken eller tolkebrukerne oppdager, kan det føre til et brudd i kommunikasjonen som ikke umiddelbart blir reparert, noe som igjen fører til at stemningen og samværssystemet kan bryte sammen (jf. Goffman, 1992, s. 20). Dette vil også få konsekvenser for senere samhandling. Tolkingens dårlige kvalitet vil derfor få ringvirkninger ut over den aktuelle ytringen eller samtalen.

Ekvivalens er nært knyttet til begrepet kvalitet i en tolkesituasjon. Ekvivalens kan defineres som kommunikativt likeverd (Lomheim, 1995, s. 29). Likeverdet har sammenheng med overføring av mening og ikke oversettelse ord for ord. $\AA$ tolke ekvivalent vil si à overholde nøyaktighetsprinsippet (Skaaden, 20013, s. 197). Det er ikke mulig å gjengi originalen 100 prosent, det vil si at en tolket versjon ikke kan gi den samme effekten som var avsenderens intensjon (Lomheim, 1995). Dette skyldes at enhver opplevelse er subjektiv, og tolkens 
dilemma er at han eller hun ikke rår fullstendig over verken intensjon eller effekt (Skaaden, 2013, s. 198-199). I tillegg vil budskapet i en tolkesituasjon først bli avkodet av tolken, for så å bli omkodet til en annen språkdrakt. Dermed vil tolken, med sin kunnskap og erfaring, påvirke budskapet. Det gjør det vanskelig å gjenskape nøyaktig den samme ytringen med tanke på intensjon og effekt. Likevel vil man alltid få en versjon som er mer eller mindre nær originalen, og tolken bør strebe etter en tolket versjon så nær originalen som mulig.

\section{Tidligere forskning}

Først på begynnelsen av 1980-tallet startet forskningen rundt selve tolkeprosessen i tegnspråktolking (Nilsson, 1997, s. 3). Det er derfor et ungt forskningsfelt, og det gjenstår fremdeles mye som det ennå ikke har vært forsket på. En del forskning på tolkesituasjoner har konsentrert seg om lingvistiske beskrivelser og analyser av språklige og syntaktiske sider av en tolkeprosess. Studien som det refereres til her fokuserer på samhandlingen der det tolkes fra tegnspråk til norsk tale (Urdal, 2011), og jeg har ikke lyktes i å finne andre forskningsprosjekt som fokuserer på det samme. Derimot har Cecilia Wadensjös forskning og arbeid om kommunikasjon og samspill mellom ulike parter i tolkede situasjoner mellom to talespråk vært et utgangspunkt for denne studien.

Intensjonen med denne studien har vært å legge til rette for at døve tolkebrukere og tolkers ulike perspektiver på tolking fra tegnspråk til norsk tale kan komme til syne. Som offentlig godkjent tolk for døve, døvblinde og døvblitte i snart 15 år er jeg interessert i emnet. Min forforståelse har påvirket mitt valg av perspektiv og som forsker har jeg forsøkt à være våken for det som Alvær og Øyen kaller «hjemmeblindhet» (1997, s.73-74).

\section{Gjennomføring av studien}

I en tolkesituasjon er det døve, tolker og hørende som gjennom kommunikasjon og samhandling er skapere og formidlere av mening. De konstruerer sine individuelle forståelser og beretninger gjennom sine sosiale relasjoner (jf. Goffman 1992, s. 17). Min studie har et sosialkonstruksjonistisk perspektiv, som også er i tråd med Wadensjös samspillfokus. Med min problemstilling, som undersøker tolkesituasjoner med hovefokus på tolking fra tegnspråk til norsk, er det samspillet i situasjonen mellom døve tolkebrukere og tolken jeg setter søkelyset på (Urdal, 2011, s.8). Hva kan gjøre opplevelsen av situasjonen god, eller mindre god, for begge parter? Jeg har forsøkt å se hva som må til for å legge til rette for god kommunikasjon og dermed god kvalitet på tolkingen. Gjennom en kvalitativ

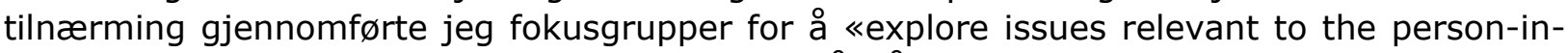
context» (jf. Wilkinson, 1998, s. 112). For å få frem døve tolkebrukere og tolkers opplevelser av samspillet, ble de invitert til å delta $\mathrm{i}$ fokusgrupper. Tre døve deltok $\mathrm{i}$ en fokusgruppe og tre hørende tolker deltok i en annen. Fokuset var på tolking fra tegnspråk til norsk tale, samspill og samhandling. I fokusgruppene fikk deltakerne mulighet til å dele og sammenligne hverandres erfaringer, og gjennom gruppeprosessen kom det frem en kompleksitet i den sosiale praksis rundt slik tolking som kanskje ikke hadde vært mulig ved individuelt intervju (jf. Halkier, 2002, s. 17). Begge gruppene hadde ett treff hver der alle bidro med sine erfaringer og tanker. Deltakerne i begge gruppene var innad veldig ofte enige med hverandre, uten at jeg oppfattet dette som påtvunget. De hadde rett og slett mange felles erfaringer og tanker som de ønsket å dele med hverandre. Jeg var til stede i begge gruppene og prøvde å tilrettelegge for diskusjon rundt temaet, og stimulere til erfaringsutveksling. 


\section{Dokumentasjon og analyse}

Diskusjonen i begge gruppene ble tatt opp på film med flere kameraer i ulike vinkler. Dette ble gjort fordi fokusgruppen med døve deltakere foregikk på tegnspråk. I tillegg er min erfaring at tolker noen ganger bruker tegnspråk for å understreke sine poeng. Dermed var kamera nødvendig for å fange opp alle språklige ytringer.

Etter fokusgruppene ble alle videoene transkribert for å få med seg det rike innholdet $\mathrm{i}$ dataene og for å kunne gjennomføre en detaljert og nøyaktig analyse (jf. Bloor, 2001, s. 59). Videoene med tegnspråk ble i tillegg tolket fra tegnspråk til norsk før de ble transkribert. Det ble gjort en oversettelse mening for mening og ikke en oversettelse ord for ord (jf. Metzger, 1999, s. 4).

Anonymitet, konfidensialitet og betryggende bruk av data er viktig i en forskningsprosess (Alver \& Øyen, 1997, s. 112), så også her. Prosjektet er godkjent av Norsk samfunnsvitenskapelig datatjeneste. I tillegg undertegnet fokusgruppedeltakerne en samtykkeerklæring.

Gjennom analyser har jeg forsøkt å oppdage de tanker og erfaringer som styrer døve tolkebrukere og tolkers atferd - handlinger som blir benyttet i dagliglivet for å konstruere sosial virkelighet. For å synliggjøre de analytiske sammenhengene noterte jeg ned i stikkord hva deltakernes uttalelser handlet om. Stikkord som var felles for uttalelsene både hos døve og tolker, ble igjen gruppert. Hva disse grupperingene pekte tilbake på ble deretter skrevet ned. Det er dette Garfinkel kaller indexicality (indeksikalitet) (1984, s. 11). Transkripsjonene ble lest gjentatte ganger, for å belyse data fra forskjellige perspektiv og for å se hvordan de ulike delene påvirket hverandre, noe som samsvarer med Garfinkels begrep reflexivity (refleksivitet) (1984, s. 9). Hvilke utfordringer døve og tolker opplever i tolking fra tegnspråk til norsk tale, og hvordan partene løser disse utfordringene, bidrar til å kaste lys over hvilke faktorer som skaper kvalitativt gode tolkesituasjoner.

\section{Situasjonens utfordringer}

Både tegnspråk og norsk tale er verbale symbolsystemer, naturlige, spontane og menneskelige kommunikasjonsformer i muntlig, ikke-grafisk form. Tolking mellom tegnspråk og norsk tale skiller seg likevel fra annen språktolking ved språkenes ulike produksjons- og persepsjonskanaler og at språkene uttrykkes henholdsvis simultant og sekvensielt (Schröder, 2006, s. 80-81). Tegnspråk er et gestuelt-visuelt språk som oppfattes via synet, mens norsk tale på sin side er et vokalt-auditivt språk og oppfattes ved hørselen. Tegnspråk uttrykkes simultant, ved å bevege hender, munn og kropp samt ansiktsmimikk. I tegnspråk brukes også fenomenet lokalisasjon. Tegnene har derfor ikke bare en mening i seg selv, men også tegnenes plassering, relasjon og interaksjon i forhold til hverandre vil uttrykke noe (Schröder, 2006, s. 87). Når man kan ta ordet er basert på ulike signaler (gestuelt og vokalt), derfor gjør språkenes ulike modaliteter turtakingen mer utfordrende.

Norsk og tegnspråk har også ulik normering. Det norske språket har blitt forholdsvis grundig beskrevet grammatisk, noe som har dannet konvensjoner og regler for hvordan man kan snakke og skrive norsk. Språkbrukerne har fått mange års opplæring i bruk av språket, gjennom skolegang og språktilegnelse på andre arenaer som hjemme eller ute blant venner. Tegnspråk har også egen grammatikk, men den er ikke like mye beskrevet. Språkbrukerne har kanskje heller ikke fătt den samme type opplæring i norsk tegnspråk som den som blir gitt i norsk tale- og skriftspråk. Døve og tunghørte med tegnspråk som førstespråk fikk ikke lovfestet rett til undervisning i og på tegnspråk før i 1996 (Handberg, 2008, s. 73). Bare ca. 10 prosent av døve barn har døve foreldre (Breivik 2007, s. 15), 
dermed har de fleste tilegnet seg språket gjennom kommunikasjon med døve venner og andre tegnspråkbrukere som de har hatt kontakt med, gjerne samtidig som foreldrene har blitt kurset (Zahl, 2000, s. 25).

På en tenkt språklinje mellom tegnspråk og norsk talespråk har man ulike overgangsformer som er påvirket i mer eller mindre grad av begge språk, for eksempel tegn til tale og tegn som støtte (TSS). Det er ingen klare grenser mellom formene (Schröder, 2006, s. 92). Døve og tunghørte kommuniserer ved bruk av tegnspråk eller ulike overgangsformer. I tillegg finnes det geografiske og individuelle forskjeller i tegnbruken. Dette er variabler som gjør tolking fra tegnspråk til tale mer utfordrende, spesielt med tanke på at man ikke er like sensitiv for sjanger, idiolekt og sosiolekt på fremmedspråk som man er på sitt eget morsmål (Erlenkamp, 2010, s. 19).

Deltakerne i fokusgruppene har også sitt syn på utfordringene. Tolkene forteller at det kan være utfordrende å tolke fra tegnspråk til norsk, at de lettere forstår norsk. Døve på sin side har forståelse for at tolking fra tegnspråk er utfordrende, og en av dem oppsummerer det slik:

Alle klarer på en måte å tolke fra norsk tale til tegnspråk. Altså alle kan på en måte det. Men å oppfatte tegnspråk og oversette det til tale, det er det som kjennetegner en virkelig god tolk. Mange føler det slik (Urdal, 2011, s. 38).

Ifølge Vission (1991, s. 12) er talespråktolkers oppfatning at tolking til sitt morsmål er lettere enn tolking fra sitt morsmål, men uttalelsene i begge fokusgruppene tyder altså på det motsatte.

En faktor som gjør at tolkene kan føle at tolking til tegnspråk er lettere, er at der tillater de seg å ta i bruk ulike «snarveier» og ad-hoc-løsninger. Tolkene dikter tegn hvis de ikke har et, de viser første bokstaven i ordet og er tydelig på ordbildet (munnen). Disse variantene kan bli oppfattet av døve. Men tolkene kan ikke benytte seg av dem når de tolker til norsk å dikte ord og bare ytre begrep med den første bokstaven vil ikke fungere. Likevel mener en av tolkene i fokusgruppen at kvaliteten på tolkingen er bedre ved tolking til norsk, for når tolken først forstår og avleser døve riktig, blir de norske setningene ekvivalente. Dessuten er evalueringsmulighetene størst i slike situasjoner, fordi man kan høre seg selv snakke, men ikke se seg selv snakke tegnspråk.

\section{Kontroll}

En sentral antakelse hos Goffman (1992, s. 22) er at mennesker ønsker à kontrollere andres inntrykk av dem. Det kan føre til en idealisering av deres opptredener (Goffman, 1992, s. 13). Som de fleste andre ønsker også døve å kontrollere hvilke uttrykk de gir og avgir. Døve i fokusgruppen har opplevd situasjoner der de ikke ble forstått av tolken, og de har sett tolker som måper og stotrer. Det har gjort dem pinlig berørte, usikre og utrygge. De har kjent ubehag og frustrasjon, noe som har gjort dem irritert på tolken. De uttrykker at slike historier er med på å gi hørende et dårlig inntrykk av døve (Urdal, 2011, s. 54).

Tolkene på sin side ønsker også kontroll i situasjonen. I fokusgruppen forteller de om tolkesituasjoner der betingelser som språk, språknivå og bruk av ukjente eller upresise tegn blir endret, slik at det dukker opp problemer i forståelsesfasen. Det har resultert både $\mathrm{i}$ hjertebank og at de har «gått på trynet», noe som har resultert i at de føler de sitter igjen som syndebukken og en dårlig stemmetolk (Urdal, 2011, s. 55).

Siden tolking er en tjeneste som produseres, leveres og konsumeres samtidig, vil en stor del av kvalitetssikringen måtte skje i forkant av tolkingen. Det er ikke alltid slik at tolkens utdanning og personlige kvalifikasjoner er tilstrekkelig for å levere tolking av god kvalitet 
(Skaaden, 2013, s. 247). $\AA$ være forberedt er en viktig betingelse for kvalitetssikring for begge parter, og for å kunne beherske situasjonen. For tolkene i fokusgruppen er det viktig å være forberedt på hvem de skal tolke for, hva de skal tolke (tema og situasjon) samt hvilken tolkemetode de skal bruke. Forberedelse er også viktig for døve i fokusgruppen, for da er de tryggere og mer avslappet, og de kan ha fokus på det de skal legge frem. Den aller viktigste forberedelsen for tolken er å vite tilstrekkelig om den de skal tolke. Det er faktisk ofte det som er bestemmende for om de ønsker tolkeoppdraget eller ikke. En av tolkene i fokusgruppen sa også: «Jeg hadde aldri meldt meg på et stemmetolkoppdrag [tolking fra tegnspråk til norsk tale] for en person jeg visste at jeg ikke forstod» (Urdal, 2011, s. 56). Det kan tyde på at tolkens bevissthet rundt forskjeller i bruk av tegnspråk, ideolekter, sosiolekter og tegnspråkets normering gjør seg gjeldende i valg av oppdrag.

Kjennskap til tolken og dens kvaliteter er også veldig viktig for de døve i fokusgruppen, spesielt i situasjoner som er viktige og betydningsfulle for dem. Ved à bestille en tolk de kjenner til, prøver de å skaffe seg mer kontroll over situasjonen. Døve har begrenset mulighet til å kontrollere tolkens ytelser i situasjonen, men det vil ikke si at de tar kvaliteten for gitt. Tillit spiller en viktig rolle når de trenger tolk, og den tolken som blir valgt, er ikke nødvendigvis den som har best karakterer eller mest utdanning, men oftere den som har en tilknytning til det døve/tegnspråklige miljøet. Denne måten å velge ut på kan sees i sammenheng med tolkeyrkets utvikling. Historisk sett var døve aktører fra døvemiljøet de første pådriverne for utforming av tolkeprofesjonen (Sander, 1999, s. 1718). Fra 1960 og frem til tolkeforbundet ble stiftet i 1978, var døveorganisasjonen eneaktør i utdanning av tolker. De hadde ansvaret for autoriseringen av tolkene helt frem til staten formelt overtok på slutten av 1970-tallet (Woll, 1999, s. 144-145). Denne overgangen gjorde at døves kontroll og oversikt over tolkeutdanningen gradvis ble mindre. Dermed har avstanden mellom utdanning og miljø blitt større. Tolker som ofte blir valgt til oppdrag som er betydningsfulle for døve tolkebrukere, er nettopp de som regnes som en del av det døve/tegnspråklige miljøet - en del avinn-gruppen; «oss døve». De tre døve i fokusgruppen mener at både gode praktiske ferdigheter og kulturell kompetanse er det som kjennetegner en god tolk (Urdal, 2011, s. 82). For dem er det viktig at tolken er godt kjent med og $i$ døvemiljøet. De sier at de beste tolkene har en forankring $i$ et tegnspråklig miljø, enten ved å ha døve i nær familie eller gjennom å jobbe på en tegnspråklig arbeidsplass. Dette er faktorer som gjør døve trygge på at tolkingen er av god kvalitet.

En førsamtale mellom døv og tolk før tolkeoppdraget er et annet element deltakerne i fokusgruppene er enige om kan bidra til à heve kvaliteten (Urdal, 2011, s. 56-57). I en førsamtale har døve og tolker mulighet til å bli kjent med hverandres kommunikasjonsform, bruk av språk og temaet det skal snakkes om. Kvaliteten på førsamtalen er også viktig. I noen tilfeller holder det å snakke om løst og fast, men i andre tilfeller bør man tilrettelegge førsamtalen slik at forberedelsen blir så reell som mulig og effekten blir størst mulig. Goffman (1992, s. 184) mener at når det ikke foreligger noen informasjon mellom partene fra før, vil det som skjer og oppfattes under interaksjonen være forholdsvis utslagsgivende. Som en døv deltaker i fokusgruppen sier: «Hvis man går rett til tolkingen, huff a meg. Jeg har opplevd det også» (Urdal, 2011, s 58). Hvis man derimot blir kjent med hverandre og med temaet, vil man være tryggere i situasjonen. Døve og tolker i fokusgruppene har ulik oppfatning om hvem som tar initiativ til førsamtalen. Begge etterlyser initiativ hos den andre part, noe som tyder på at førsamtalen er viktig for dem.

Jo mer man føler at man kontrollerer en situasjon, jo mer uavhengig kjenner man seg (Helgøy, Ravneberg \& Solvang, 2003, s. 471). Døve har reduserte muligheter til a kontrollere tolken i en tolkesituasjon. Noen døve i fokusgruppen sier de forsøker å styre tolken ved å ytre setninger med norsk syntaks med mer eller mindre bruk av tegn som støtte (TSS) eller sin egen stemme (Urdal, 2011, s. 54). Dermed påvirke de tolkene til å 
foreta en «intralingual translation» (jf. Lomheim, 1995, s. 17). Tolken vil da gjenta uten a oversette, bare legge stemme på. Da føler døve at de har større kontroll på uttrykk de gir og kvaliteten på setningene som produseres. Men det er ikke alle døve som har denne muligheten. Tolkene er ofte de eneste i situasjonen som har tilgang til begge språk, og kontroll over ressurser er grunnlag for makt (jf. Gulbrandsen, 2000, s. 75). Begge parter er bevisst tolkens makt. En av tolkene i fokusgruppen sier det slik: «Vi har mye makt når vi driver på [tolker]. Vi er dem som styrer begge linjene» (Urdal 2001, s.59). Døve ønsker at tolkene skal bruke makten for å gjøre det mulig for dem å bli mer delaktige i kommunikasjonssituasjoner. Dette mener de tolkene kan gjøre ved å tilrettelegge turtakingssystemet for å kompensere for at budskapet kommer frem til døve noen sekunder senere på grunn av oversettelsesarbeidet ved simultantolking. Dette kan kobles til tolkenes kjennskap til turtakingsreglene i begge språk, og det at de lettere kan ta i bruk de indeksikale tegnene for å skape samtaleflyt.

Et annet moment for å kvalitetssikre tolkingen gjøres av tolkene selv. Tolkene i fokusgruppen sier de ønsker at døve skal ta mer kontroll. De vil at døve skal bry seg mer med prosessen ved å bli stemmetolket, og for å bidra til dette gir tolkene døve kontrollen ved å signalisere hva de stemmetolker. De gjør det ved å sjekke ut om de tolker riktig (Urdal, 2011, s. 45). Tolkene er opptatt av å formidle ekvivalent, og det å sjekke ut er en viktig del av tolkesituasjonen for dem. Ved å bøye seg litt fremover og gjenta tegn på en litt spørrende måte, vil de at døve skal sjekke om tolken har oppfattet riktig. Mimikk og blikk blir brukt i kontakten mellom døv og tolk, for å få bekreftet det som ble oppfattet, eller for å signalisere at den døve må gjenta noe. «Når jeg bruker det, da som oftest fungerer det godt», forteller en av tolkene i fokusgruppen (Urdal, 2011, s. 45). En døv deltaker i fokusgruppen ønsker det samme tilbudet til alle involverte; tolken bør sjekke ut med både den døve og den hørende, i tillegg til at den døve bør ha muligheten til å stoppe og spørre tolken om hun har forstått (Urdal, 2011, s. 46).

Gjennom å se hvordan de andre i situasjonen reagerer og ved å munnavlese tolken kan døve til en viss grad sjekke ut tolken. Døves funksjonelle tospråklighet (tegnspråk og norsk) kan til dels gjøre det mulig for dem à munnavlese tolken, og dette kan skape en forventning om kontroll av det tolken tolker. Men samtidig mangler mange døve tolkekompetanse på oversettelse av mening for mening heller enn ord for ord, og de kan bli usikre når tolken tar i bruk andre ord eller en annen dialekt. Det er med andre ord utfordrende og komplisert for døve å sjekke ut tolken og kontrollere kvaliteten i en tolkesituasjon. Målet for begge parter er å etablere en situasjon med god tolking; døve ønsker å bli forstått av tolken og derigjennom bli forstått av hørende. Tolkene vil forstå og oversette døves ytringer ekvivalent. Manglende muligheter for kontroll aktualiserer behovet for tillit.

\section{Tillit}

Tolkede situasjoner krever samarbeid mellom den hørende, den døve og tolken. Situasjoner som krever samarbeid bygger ofte på en kombinasjon av gjensidig overvåkning og kontroll, og tillit (Grimen 2009, s. 73 \& 80). Etablering av tillitt blir viktig, og både døve og tolker $\mathrm{i}$ fokusgruppene snakket om tillit og kjemi som noe de syntes var grunnleggende i enhver god situasjon (Urdal, 2011, s. 41).

Tillit kan forstås fra flere perspektiver. Gulbrandsen (2000) beskriver tillit som

en viktig bestanddel av vår hverdag og vevd inn i mange av våre relasjoner med andre mennesker, ofte uten at vi tenker noe større over dette. Tillit er dessuten en betingelse for at vi skal kunne gjennomføre svært mange av våre gjøremål (s. 67). 
Tillit kan bidra til at døve, hørende og tolker våger å samarbeide med hverandre for å gjøre kommunikasjonssituasjonen best mulig. I fokusgruppene bruker døve begrepet tillit, mens tolkene bruker begrepet kjemi. Benevnelsene er ulike, men samtalene i fokusgruppene viser at de favner mye av det samme. Døve bruker ordet tillit som et overordnet begrep om noe som gjør dem trygge. Det rommer tolkens faglige kvalifikasjoner, tolkens imøtekommenhet før, under og etter tolkesituasjonen, og ellers alt det andre de mener må være til stede i en godt fungerende tolkesituasjon. Tilliten bygges på egne eller andres erfaringer med tolken. Tolkene på sin side bruker begrepet kjemi for å karakterisere «et eller annet som fungerer». Det rommer forholdet mellom dem selv og den døve i situasjonen, men det rommer også hvordan tolkene forholder seg til hørende og sine egne faglige ferdigheter. En av tolkene i fokusgruppen påpekte at gode situasjoner karakteriseres av god kvalitet, god samtaleflyt og at «... folk er fornøyd» (Urdal, 2011, s. 42).

Deltakerne i fokusgruppene nevner at tillit kan oppstå umiddelbart, noe som er en fordel da tolker og den døve ofte møtes bare én gang. «Noen tolker er bare veldig gode, rett og slett», sier en av de døve deltakerne (Urdal, 2011, s. 43). Tilliten her bygger altså på tolkens evne til å oppfatte, og på en følelse av å bli forstått. For tolkene bygger den på at døve må vise tolkene respekt og at døve åpner opp for samtaler både før og etter tolkesituasjonen. Da blir tolkene sett og tatt hensyn til, og de føler det kan bli en god situasjon.

Tillit oppstår lettest i langvarige og stabile relasjoner mellom mennesker siden tillitsdannelse er en prosess som kan ta tid (Gulbrandsen, 2000, s. 72). Det er også slike situasjoner deltakerne i fokusgruppen henviser mest til. De snakker om situasjoner der man finner frem til egne samarbeidsteknikker som fungerer for begge parter og som gjør dem trygge. Denne økende trygghetsfølelsen over tid gjør at tilliten opparbeides.

Begge gruppene ønsker ̊̊ oppnå trygghet. Døve i fokusgruppen forbinder følelsen av trygghet med tillit, det vil si at hvis de er trygge, făr de tillit til tolken. En tolk som tar initiativ til førsamtale kan bidra til å skape grunnlaget for tryggheten og tilliten (Urdal, 2011, s. 42). Engasjement og forpliktelse til samarbeid vil fungere oppbyggende (Kale og Larson, 1998, s. 6), mens tolker som er passive i forkant av tolkesituasjonen kan være med på å skape en usikkerhet hos døve: Vil tolken forstå meg? Tolkens holdninger til samarbeid er for døve også knyttet til tillit. Tolker som oppleves som lite ydmyke og fraskriver seg ansvaret i situasjonen, gjør samarbeid og tillit vanskelig.

Holdninger er også noe de tre tolkene i fokusgruppen forbinder med kjemi. De bruker begrepet romslighet om døves holdninger og om hvordan de blir møtt av døve (Urdal, 2011, s. 42). Romslighet gjør at tolkene føler seg velkommen og at det er en aksept for at tolkene kan be døve gjenta hvis tolken ikke forstăr. God kjemi er å bli sett av den døve, å føle seg velkommen. En av tolkene i fokusgruppen nevner også at ved å informere om sin rolle og tre frem som tolk, gjør hun situasjonen lettere å håndtere for alle. Hun gjør dermed seg selv synlig for å skape god kjemi. Respekt er en annen viktig faktor her. Tolkene er opptatt av å være likeverdige med døve, at de skal ha en likeverdig respekt for hverandre. Gjensidig respekt er en vesentlig bestanddel i gode tillitsforhold (Kale og Larson, 1998, s. 6), og hvis tolkene opplever å bli sett på som «et nødvendig onde», blir de utrygge og trekker seg litt tilbake. I gode situasjoner blir de respektert og godtatt, slik en av tolkene i fokusgruppen beskriver det:

Og det er liksom sånn du kjenner med en gang. Ok, at her er det liksom, her er det ok at du kommer inn. Ja, da blir du liksom trygg og roer litt ned og ... ja. Da tåler du mer, når du er trygg og har fått roet deg i situasjonen. Ja, da gjør du en bedre jobb som tolk (Urdal, 2011, s. 43). 


\section{Tillit og kvalitet}

Gulbrandsen (2000, s. 84) hevder at tillit handler om hvordan en profesjonsutøver oppfører seg ut over kvalifikasjonene og kvaliteten på det arbeidet vedkommende utfører. I situasjoner der det tolkes fra tegnspråk kan vi se at tillit og kvalitet henger tett sammen, men døve og tolker i fokusgruppene opplever denne sammenhengen på ulike måter.

Døve på sin side får tillit til tolken hvis tolken forstår dem. Tilliten baseres i hovedsak på egne eller andres erfaring med tolkens gode kvalitet. En opplevelse av god kvalitet gir grobunn for tillit. En av de døve deltakerne i fokusgruppen setter også likhetstrekk mellom tillit og frihet: «Jeg opplever det slik at jeg har en tillit til tolken. Jeg ser ikke på tolken, jeg bare tegner [bruker tegnspråk] til publikum som er til stede. Jeg tegner helt fritt» (Urdal, 2011, s. 49). Behovet for å sjekke tolken er ikke til stede; tilliten er total. Og jo tryggere man er, jo færre forholdsregler tar man. Slik vil tilliten ikke vises i det vi gjør, men i det vi ikke gjør (Grimen, 2009, s. 49). Tolken vil i slike situasjoner oppleves som usynlig: «Og i etterkant kan jeg faktisk ikke huske om jeg har brukt tolk eller ikke, selv om tolken har vært til stede hele tiden» (Urdal, 2011, s. 49). Tolken er der, men er ikke merkbar.

Tolkene i fokusgruppen opplever dette på en annen måte. Hvis tolkene blir akseptert som en del av situasjonen, allerede fra de kommer inn, føler de seg velkommen. Tolkene har et behov for blikkontakt med de døve og bli sett i tolkesituasjonen. Hvis tolken stadig har blikkontakt med den døve under selve tolkingen og den døve gir tilbakemelding (for eksempel i form av et nikk) til tolken som et tegn på at oversettelsen er ekvivalent, gjør det tolken trygg. Når døve tar hensyn til tolken, gir de en indikasjon på at de vil samarbeide, og det gir tolken trygghet. Denne tryggheten gjør at tolken føler tillit til den døve, som igjen bidrar til at kvaliteten på tolkingen blir god. Når det motsatte skjer; når døve har urealistiske forventninger til tolken og ikke har blikkontakt med tolken, er det mer utfordrende for tolken à tolke. Tilliten er borte, og kvaliteten lider. Tilliten blir her en forutsetning for kvalitet, i motsetning til at kvalitet er en forutsetning for tillit, slik det er for døve. Det gjør situasjonen utfordrende og kan skape en spenning mellom døve og tolker.

\section{Avslutning}

Kommunikasjon og språklige forskjeller gjør tolkeprosessen utfordrende. I tillegg fører reduserte muligheter for kontroll til at partene gjør ulike grep for å bli trygge i situasjonen. Tillit er her viktig for begge parter, men tillit opparbeides på ulike måter hos døve og hos tolker. Dersom døve tolkebrukere opplever tolkingen som god, fører det til tillit til tolken. Tolkene på sin side er avhengig av tillit for å kunne yte best mulig (tolking) i situasjonen. For å oppnå god kvalitet $\mathrm{i}$ tolkesituasjonen kan åpenhet rundt denne ulikheten være et godt utgangspunkt. En forventningsavklaring og gode samarbeidsrutiner kan bidra til at begge parter føler seg trygge. Skaaden (2013, s. 251) nevner viktigheten av før- og ettersamtaler mellom tolk og fagperson, slik deltakerne i fokusgruppene påpeker at førsamtaler er viktig for tryggheten i situasjoner der det tolkes fra tegnspråk til norsk tale. Tolking av god kvalitet er viktig for at døve skal kunne realisere seg selv i de situasjonene de deltar i. $\AA$ forvente kvalitet fra tolkene uten selv å bidra, kan ikke kalles samarbeid, og nøkkelen i denne situasjonen er kanskje nettopp det - samarbeid. Manglende kunnskap om og forståelse for tolkens oppgave kan redusere tolkingens kvalitet (Skaaden, 2013, s. 239). Dermed er det viktig at tolkene gir informasjon om sin rolle og inviterer til samarbeid. Med sin utdannelse har tolkene et ansvar for kvaliteten på sitt arbeid, men de kan ikke gjøre det uten gode rammevilkår og samspill med de andre partene i situasjonen. Kommunikasjon og samarbeid må til. På hvilken måte og hvilke former dette samarbeidet skal ha, bør bli en diskusjon mellom partene. 


\section{Referanser}

Alvær, B.G. \& Ø. Øyen (1997). Forskningsetikk i forskerhverdag: vurderinger og praksis. Oslo: Tano Aschehoug.

Bloor, M. (2001). Focus groups in social research. London: Sage.

Breivik, J.K. (2007). Døv identitet i endring. Oslo: Universitetsforlaget.

Brofoss, K. (2012). Arbeidsrettede tiltak. NOU 2012:6. Oslo: Departementenes servicesenter.

Erlenkamp, S. (2010). Explaining the challenges of sign to speech interpreting. (European Forum for Sign Language Interpreters [EFSLI], Trainers' seminar). Helsinki: EFSLI.

Garfinkel, H. (1984). Studies in ethnomethodology. Cambrigde: Polity Press.

Goffman, E. (1992). Vårt rollespill til daglig: en studie i hverdagslivets dramatikk. Oslo: Pax.

Grimen, H. (2009). Hva er tillit. Oslo: Universitetsforlaget.

Gulbrandsen, T. (2000). «Om tillit». Sosiologi i dag, 30 (3), 67-95.

Halkier, B. (2002). Fokusgrupper. Fredriksberg; samfundslitteratur \& Roskilde Universitetsforlag.

Handberg, T.B. (2008). «Tospråklighet et gode». I: H. Herland (red.): Tegnspråkets

fremtid - vårt felles ansvar (s. 67-76). Bergen: Norges Døveforbund.

Helgøy, I., B. Ravneberg \& P. Solvang (2003). «Service provition for an Independent Life». Disability and Society, 18 (4), 471-487.

http://dx.doi.org/10.1080/0968759032000081011

Kale, A. \& H.W. Larsen (1998). The Deaf Professional and the Interpreter; A Dynamic Duo. Upublisert manuskript. National Center On Deafness, California State University i Northridge.

Lomheim, S. (1995). Omsetjingsteori. Oslo: Universitetsforlaget.

Metzger, M. (1999). Sign language interpreting; deconstructing the myth of neutrality. Washington: Gallaudet University Press.

Mosand, N.E. \& A.K. Malmquist (1996). Se mitt språk!: språkbok: en innføring i norsk tegnspråk. Bergen: Døves forlag AS.

Nilsson, A.L. (1997). Forskning om teckenspråkstolkning - en översikt. [Stockholm]: Stockholms universitet, Tolk- och översättarinstitutet.

Sander, T. (1999). «Før døvetolkene ble en yrkesgruppe».I: H. Woll (Red.), Døvetolk- og døvblindetolkeyrkets fremvekst i Norge (s. 13-28). Bergen: Døves Forlag AS.

Schröder, O.I. (2006). «Likt og ulikt - Innføring i forskjeller mellom norsk og norsk tegnspråk». I: S.R. Jørgensen \& R.L. Anjum (red.) Tegn som språk. Oslo: Gyldendal.

Skaaden, H. (2013). Den topartiske tolken. Lærebok i tolking. Oslo: Universitetsforlaget.

Tolkeforbundet $(2011,10$. april). Tolkeforbundets yrkesetiske retningslinjer for etikk og yrkesutøvelse. Hentet fra http://tolkeforbundet.no/main/component/content/article Lest 25.09.14

Urdal, G.H.S. (2011). Samspill ved stemmetolking - betingelser for døves deltakelse Masteroppgave i samfunnsarbeid. Bergen: Høgskolen i Bergen.

Vission, L. (1991). From Russian into English: an introduction to simultaneous interpretation. Mich: Ardis.

Wadensjö, C. (1998). Kontakt genom tolk. Stockholm: Dialogos.

Wilkinson, S. (1998). «Focusgroups in feminist research: Power, interaction, and the cocontruction of meaning». Women's Studies International Forum, 21 (1), 111-125. 
http://dx.doi.org/10.1016/S0277-5395(97)00080-0

Woll, H. (1999). «Tolkeforbundet og tolketjenesten 1988-1999». I: H. Woll (red.): Døvetolk- og døvblindetolkeyrkets fremvekst i Norge (s. 169-175). Bergen: Døves Forlag.

Zahl, T.S. (2000). Døves tospråklighet. Hovedoppgave i spesialpedagogikk. Oslo: Universitetet i Oslo. 